\title{
Evaluation of debris flow hazard to Chalala village, Quebrada de Humahuaca UNESCO World Heritage Site, Jujuy Province, Argentina
}

\author{
M. A. González ${ }^{1}$, V. Baumann ${ }^{1}$ \& L. E. Jackson Jr. ${ }^{2}$ \\ ${ }^{1}$ SEGEMAR, Capital Federal, Buenos Aires, Argentina \\ ${ }^{2}$ Pacific Division, Geological Survey of Canada, Vancouver, BC, Canada
}

\begin{abstract}
Chalala village is situated on the alluvial fan of Quebrada Chalala that is periodically affected by extensive debris flows. Servicio Geológico Minero Argentino (SEGEMAR) sought to establish the magnitude and frequency of debris flows from unmonitored Chalala basin. Analysis of historical records, oral accounts, and investigations of debris flow deposits and surveys of two debris flows in 2007 assigned Chalala and adjacent Coquena fans to high frequency and large magnitude ratings in semi-quantitative hazard rating schemes. Two methods were used to estimate the volume of the maximum likely debris flow for the purposes of debris-flow-defence design and hazard evaluation. Method one extrapolated known peak discharge/total volume relationships using a power relationship for debris (mud) flows displaying similar rheology. Method 2 involved extrapolation of known extreme sediment yield values. The methods yielded comparable results for the two basins. The method 2 estimate of $4.6 \times 10^{5} \mathrm{~m}^{3}$ is consistent with geomorphic and stratigraphic investigations and eyewitness accounts of events over the past 62 years. An additional uncertainty coefficient of 1.2 is recommended.
\end{abstract}

Keywords: debris flow, mudflow, Argentina, Andes, Humahuaca, Purmamarca.

\section{Introduction}

Debris flows and debris floods are widespread hazards throughout the Andes from Venezuela to Argentina [1-3]. Unlike analogous mountainous drainage 
basins of the European and Japanese alps and parts of the North American cordillera, most of the Andes and other mountainous areas of the developing world have sparse hydro-meteorological data collection. Under these circumstances, investigators commonly have to evaluate debris flow hazard based upon scattered written or oral accounts from local residents and deposits of historic or prehistoric debris flows. This paper describes an investigation by Servicio Geológico Minero Argentino (SEGEMER) of debris flow hazard to the recently established village of Chalala in Quebrada de Humahuaca UNESCO world heritage site, Jujuy Province, Argentina. It was carried out in conjunction with the Multinational Andean Project: Geoscience for Andean Communities (MAP:GAC), a collaborative undertaking by geological surveys of the Andean countries and Canada. We show how a mix of data sources typically available to investigators in sparsely monitored mountain regions can be combined with empirical relationships established elsewhere to evaluate debris flow hazard.

\section{Physical and climatic setting}

The new village of Chalala is located on the alluvial fan of Quebrada de Chalala (quebrada is 'creek' in English) a tributary to Río de la Quebrada de Purmamarca (Río Purmamarca) in the western half (Mitad Occidental) of the Cordillera Oriental of the Andes of northwestern Argentina (area of $23^{\circ} 43,56^{\prime \prime} \mathrm{S}$, $65^{\circ} 30^{\prime} 60^{\prime \prime} \mathrm{W}$; Fig. 1). It covers $5 \mathrm{Ha}$ and consists of 50 houses. The resort town of Purmamarca is $2 \mathrm{~km}$ to the southwest. The terrain of Cordillera Oriental closely reflects structure and lithology of an easterly verging fold and thrust belt. Peaks rise to $4200 \mathrm{~m}$ and relief in the Purmamarca area is in the 2000 to $2500 \mathrm{~m}$ range. Secondary streams cut deep, ravine-like dendritic valley systems east and

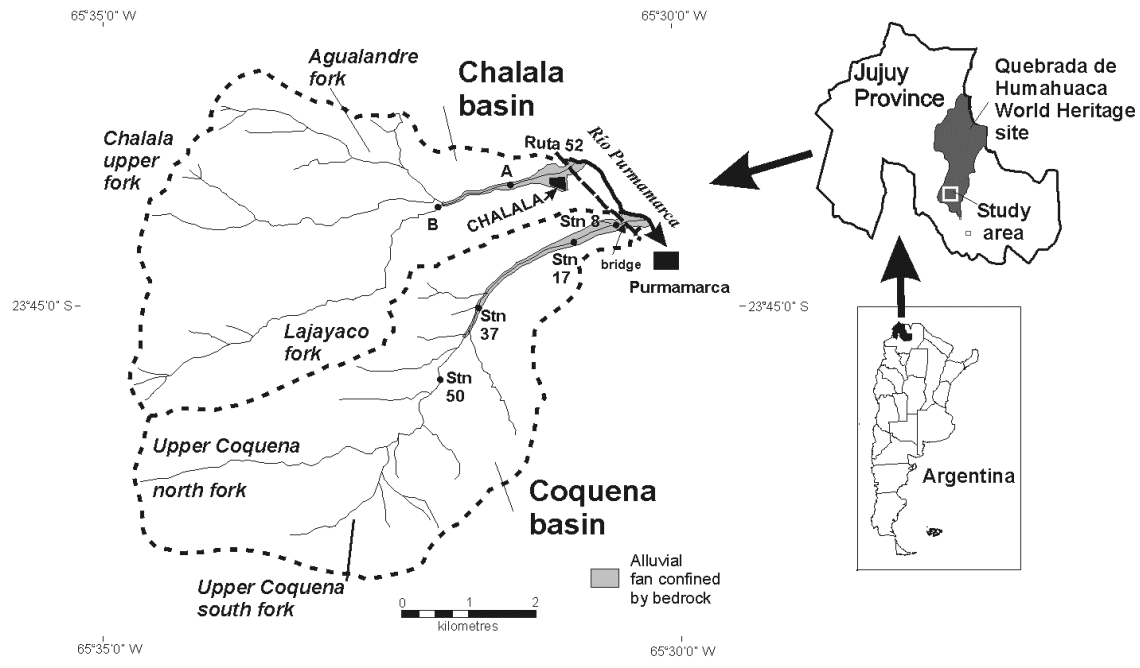

Figure 1: $\quad$ Location of study area and features referred to in text. 
west from major north-south valleys. Quebrada Chalala and adjacent Quebrada Coquena are typical examples of these tributaries (Table 1). The lower reaches of Quebrada Chalala and adjacent Quebrada Coquena occupy elongated sediment filled valleys laterally constrained by bedrock spurs rather than classic alluvial fans where stream courses are free to migrate laterally across an arc of 45 degrees or more. The macroclimate of the region is arid subtropical modified by elevation. Average temperature is in the 12 to $14^{\circ} \mathrm{C}$ range in valley locations such as Chalala. However, winter temperatures as low as $-8.8^{\circ} \mathrm{C}$ and between $30^{\circ}$ and $35^{\circ} \mathrm{C}$ throughout the year have been recorded [4]. Adjacent mountains have progressively lower maximum temperatures and increasingly rigorous physical weathering environments with altitude. Total annual rainfall is less than $200 \mathrm{~mm}$ and it occurs during the austral summer months of November to March. Relative humidity is usually less than $50 \%$ and evaporative potential is 2000 $\mathrm{mm}$. Consequently, vegetation is sparse to absent.

Table 1: $\quad$ Physiographic statistics for Chalala and Coquena basins.

\begin{tabular}{|l|l|l|l|l|l|l|}
\hline Basin & $\begin{array}{l}\text { Area } \\
\left(\mathrm{km}^{2}\right)\end{array}$ & $\begin{array}{l}\text { Max. } \\
\text { elev. } \\
(\mathrm{m} \text { asl })\end{array}$ & $\begin{array}{l}\text { Max. } \\
\text { relief, } \\
(\mathrm{m})\end{array}$ & $\begin{array}{l}\text { Channel length }(\mathrm{m}) \\
\text { /slope above fan-head } \\
(\mathrm{deg} .)\end{array}$ & $\begin{array}{l}\text { Fan area above } \\
\text { Ruta 52 }\left(\mathrm{m}^{2}\right)\end{array}$ & $\begin{array}{l}\text { Mean } \\
\text { fan } \\
\text { slope }\end{array}$ \\
\hline Chalala & 19.6 & 4178 & 1721 & $6295 / 12-17$ & $2.5 \times 10^{5}$ & $4.2^{\circ}$ \\
\hline Coquena & 19.4 & 4087 & 1621 & $3785 / 17.5$ & $3.8 \times 10^{5}$ & $4.0^{\circ}$ \\
\hline
\end{tabular}

\section{Study methods}

The regional geology and geomorphology of the area was previously studied by SEGEMAR [5]. A high resolution Ikonos satellite image was taken (June 2006) in order to study the geomorphology of the basin and prepare an accurate digital elevation model and topographic map. Although this study had as its objective the evaluation of debris flow hazard the village of Chalala, information gathered on the adjacent Quebrada Coquena basin (see below) was directly applicable to the Chalala basin. Both basins and their fans were investigated.

\subsection{Surveys of 7 and 30 March the debris flow deposits}

Width, thickness (from natural exposures) and slope angle were measured from flow toe to fan head over segments 50 to $100 \mathrm{~m}$ in length. Thickness was estimated for each segment based upon natural exposures. The volume of each segment was calculated. Volumes were considered maximum estimates and could be up to about $30 \%$ larger than true values due to lack of exposures in estimating flow thickness. Where bends in the flow path were sharp enough to cause super-elevation of a flow on the outside of the bend relative to the inside of the bend, flow velocity (v) was estimated using a the force-vortex equation (1) of Hungr [6]. Where run-up against barriers occurred, velocity was estimated using the equation (2) of Chow [7].

$$
\begin{gathered}
\mathrm{v}=((\Delta \mathrm{hr} \mathrm{g} \mathrm{j}) / \mathrm{b})^{0.5} \\
\mathrm{v}=(2 \mathrm{~g} \Delta \mathrm{h})^{0.5}
\end{gathered}
$$


where $\mathrm{v}=$ flow velocity, $\Delta \mathrm{h}=$ the difference in elevation between the inside and outside of the channel (1) or the relative run-up height (2); $g=$ acceleration of gravity $9.8 \mathrm{~m} / \mathrm{s} / \mathrm{s} ; \mathrm{r}=$ the radius of a circle approximating the curve of the channel; $b=$ the width of the debris flow across the super-elevation; and $j$ is $a$ constant assumed to be 1 for these calculations ( $\mathrm{j}$ is suggested to be 2.5 as a safety factor for design of bends in debris flow containment dikes by Hungr et al. [8]. Peak discharge was computed by multiplying channel cross sectional area immediately up-stream from the curvature in the channel where the superelevation was measured. The super-elevated cross section cannot accurately be used as a cross section because flows have been observed to have pronounced concavities during super-elevation $[9,10]$.

\subsection{Estimation of past debris flow magnitude from geomorphic evidence}

The fans and lower basins of quebradas Coquena and Chalala were traversed in order to search for evidence and sectional exposures of debris flow deposits. In the areas of fan heads, the highest and widest debris flow levees were measured. Ages of the levees were determined by ${ }^{14} \mathrm{C}$ dating or estimated from 'silent witnesses' including ages and injuries to trees (salix sp.) and cardón cactus (Echinopsis atacamensis). The latter can grow to heights of $4 \mathrm{~m}$. Their ages were estimated by assuming a vertical growth rate of $5 \mathrm{~cm} /$ year. These are minimum estimates because decades may elapse between levee deposition and establishment of the cactus. Also, it is not clear at what height, if any, vertical growth ceases.

\subsection{Interviews of eyewitnesses and compilation of written and oral history}

Witnesses of the 7 March 2007 debris flows could estimate its velocity from direct observation. Furthermore, an estimate of its average velocity traversing the length of the fan could also be computed from their accounts by dividing the fan length by their estimates of the time from the initial sound of its approach (emergence at fan head) until it passed them. Elders who lived their lives on the fans or within the basins of quedradas Coquena and Chalala documented the dates and magnitude of past debris flows. They established that debris flows were associated with intense mountain thunderstorms or regional rainstorms.

\section{Debris flows in the Purmamarca area}

Sparse vegetation and high relief make the Purmamarca area particularly prone to debris flows during periods of intense rain. Unfortunately, historical documentation of floods and debris flows only post-date 1945 (Table 2). Events all occurred during summer months (November to March) when almost all yearly precipitation falls. During these events, rain falls on the upper basins and may or may not fall in the Río Purmamarca valley. Rain fell on the mountains and valleys during the 1984 event. A surge of water and sediment was recorded on Río Purmamarca at a now abandoned Río Grande railway station $3 \mathrm{~km}$ to the 
east of Purmamarca. It appeared like a wall as it approached. It was likely a debris flood [11] rather than a true debris flow.

Table 2: Historic debris flows in Purmamarca area from written and oral accounts and surveys in 2007.

\begin{tabular}{|l|c|c|c|c|c|}
\hline Date & Chalala & Coquena & $\begin{array}{c}\text { Purma- } \\
\text { marca }\end{array}$ & $\begin{array}{c}\text { Max length } \\
\text { width }(\mathrm{m})\end{array}$ & $\begin{array}{c}\text { Est. total vol. } \\
\left(\mathrm{m}^{3}\right)\end{array}$ \\
\hline 2007 (7 Mar.) & & $\mathrm{X}$ & & $4100 / 116$ & $\begin{array}{l}1.1 \times 10^{5}- \\
1.5 \times 10^{5}\end{array}$ \\
\hline 2007 (29 Mar.) & $\mathrm{X}$ & & & $2296 / 42$ & $1.6 \times 10^{4}$ \\
\hline $2002^{\mathrm{b} .}$ & & $\mathrm{X}$ & & -- & $<2007$ event \\
\hline 1986 (Nov. 11) & $\mathrm{X}$ & & & $2296 / 100$ & Unknown \\
\hline $1984(11 \mathrm{Feb})$. & & & $\mathrm{X}$ & -- & -- \\
\hline 1970 (Dec. $)$ & $\mathrm{X}$ & & & -- & -- \\
\hline $1970(8 \mathrm{Feb})$ ) & & & $\mathrm{X}$ & -- & -- \\
\hline 1960 (Feb $)$ & & & $\mathrm{X}$ & -- & -- \\
\hline 1957 (late Dec.) & $\mathrm{X}$ & & & -- & volcán $n^{\mathrm{c} .}$ \\
\hline $1949^{\mathrm{b} .}$ & & & $\mathrm{X}$ & -- & -- \\
\hline $1945^{\text {b. }}$ & $\mathrm{X}$ & & & & \\
\hline
\end{tabular}

a. Lengths determined from fan head; b. day and month uncertain; c. lahar-scale mudflow.

\subsection{Investigation of 7 and 29 March 2007 debris flows}

Table 3 summarizes the unified soil classification and Atterberg limits for samples from 7 and 29 March debris flows. Locations of points referred to in the discussion are shown in Fig. 1. The debris flow of 7 March 2007 reached the head of the fan of Quebrada Coquena at approximately 5 AM. It followed a thunderstorm over the basin of Quebrada Coquena an hour earlier. A witness who lives within the drainage identified the north fork of Quebrada Coquena as the source of the mudflow (Fig. 1). It travelled the $4 \mathrm{~km}$ length of the fan in an estimated 10 to 15 minutes for an estimated average speed of 4-7 m/s. A witness at station 8 (channel gradient 3.5 degrees) about $150 \mathrm{~m}$ above the Ruta 52 bridge described the flow as very turbulent. He estimated the flow velocity to have been faster that he could run to save his life (at least 5 to $6 \mathrm{~m} / \mathrm{s}$ for a young man is a reasonable estimate) and noted that the flow continued for about 10 minutes. The fluidity and turbulence of the flow on a very low gradient clearly indicate that it was a mudflow despite its borderline plasticity index of 4.9 (Table 5) that places it just below the mudflow classification of Hungr et al. [8] $(>5 \%)$. It descended channels along the lower fan with gradients as low as 3 degrees and transported clasts up to $43 \mathrm{~cm}$ in maximum diameter to Río Purmamarca. Clasts up to 180 $\mathrm{cm}$ in maximum diameter were transported to the fan head. Approximately 2300 $\mathrm{m}^{3}$ of stony muddy debris passed a vertical gap about $1 \mathrm{~m}$ high and $12.7 \mathrm{~m}$ in width on a gradient of 3 degrees between bridge and channel floor (Figs. 3 and 4). High pore pressures remained in the debris flow deposits as late as 13 March: sediments still spontaneously flowed in excavations near the highway bridge at that time. In many areas, the bouldery facies of the debris flow was buried by muddy after-flow facies. 
Table 3: $\quad$ Classification debris flow samples.

\begin{tabular}{|l|l|l|c|c|c|c|}
\hline Sample & Fan & Source & USC & LL (\%) & PL (\%) & PI (\%) \\
\hline 36 & Chalala & Pre-2007 deposit & SC & 21.9 & 14.5 & 7.4 \\
\hline 38 & Coquena & Fresh flow & SM-SC & 23.7 & 18.8 & 4.9 \\
\hline 39 & Chalala & Fresh flow & GP-GM & 26.3 & 21.5 & 5.2 \\
\hline 40 & Chalala & Fresh flow & no data & 24.5 & 16.4 & 8.1 \\
\hline
\end{tabular}

Table 4: $\quad$ Summary of velocity and discharge data determined from a survey of 7 March, 2007 debris flow from Quebrada Coquena.

\begin{tabular}{|c|c|c|c|c|c|c|}
\hline Stations & $\Delta \mathrm{h}(\mathrm{m})$ & $\mathrm{b}(\mathrm{m})$ & $\mathrm{r}(\mathrm{m})$ & $\mathrm{v}(\mathrm{m} / \mathrm{s})$ & $\begin{array}{l}\text { X-section } \\
\text { area }\left(\mathrm{m}^{2}\right)\end{array}$ & $\begin{array}{l}\text { Max } \\
Q\left(\mathrm{~m}^{3} / \mathrm{s}\right)\end{array}$ \\
\hline \multicolumn{7}{|c|}{ Super-elevation method (equation 1) } \\
\hline $50-1$ & 3.4 & 14 & 55 & 7.7 & 62 & 477 \\
\hline $50-2$ & 3.4 & 14 & 55 & 7.7 & 40 & 308 \\
\hline $50-3$ & 4.1 & 14 & 55 & 8.5 & 62 & 527 \\
\hline $50-4$ & 4.1 & 14 & 55 & 8.5 & 40 & 340 \\
\hline $17-1$ & & & & 4.7 & & \\
\hline \multicolumn{7}{|c|}{ Run-up method (equation 2) } \\
\hline $50-5$ & 3.4 & & & 8.2 & 62 & 508 \\
\hline $50-6$ & 3.4 & & & 8.2 & 40 & 328 \\
\hline $50-7$ & 4.1 & & & 9 & 62 & 588 \\
\hline $50-8$ & 4.1 & & & 9 & 40 & 360 \\
\hline $37-1$ & 1 & & & 4.4 & - & - \\
\hline $17-2$ & 1 & & & $3.6-4.6$ & - & - \\
\hline \multicolumn{7}{|c|}{ Eyewitness and other estimates } \\
\hline Average & y along le & gth of $f$ & & $4.6-7$ & - & - \\
\hline
\end{tabular}

Table 5: Ages of largest prehistoric debris flows, quebradas Coquena and Chalala.

\begin{tabular}{|l|l|l|}
\hline $\begin{array}{l}\text { Basin/Sub-basin or } \\
\text { fan }\end{array}$ & $\begin{array}{c}\text { Age } \\
\text { (years) }\end{array}$ & Control and other comments \\
\hline $\begin{array}{l}\text { Chalala/ } \\
\text { Agualandre }\end{array}$ & $\begin{array}{l}>200- \\
300\end{array}$ & Minimum est. age of cardón cactus growing on highest levee. \\
\hline Chalala/ Chalala & $<670$ & $\begin{array}{l}{ }^{14} \mathrm{C} \text { age } 620+/-80 \text { bp (Beta 231191) detrital wood in highest } \\
\text { debris flow deposits. }\end{array}$ \\
\hline Chalala/Lajayaco & $\begin{array}{l}>200- \\
300\end{array}$ & $\begin{array}{l}\text { Minimum age estimate from estimated age of cardón cactus } \\
\text { growing on deposit. }\end{array}$ \\
\hline $\begin{array}{l}\text { Chalala: deposit } \\
\text { on fan }\end{array}$ & $\begin{array}{l}1957 \\
\text { event? }\end{array}$ & $\begin{array}{l}1.4 \text { to } 2 \text { m thick debris flow deposits in bank of q. Chalala (pt. } \\
\text { A, Fig. 1). Unvegetated except for scattered small bushes. }\end{array}$ \\
\hline $\begin{array}{l}\text { Coquena; station } \\
50\end{array}$ & $\begin{array}{l}>200 ? \\
\text { flows }\end{array}$ & $\begin{array}{l}\text { Willow tree growing on highest levee (est. }>100<200 \text { years) It } \\
\text { was damaged by debris flow larger than 2007 during its life. }\end{array}$ \\
\hline
\end{tabular}

The 29 March debris flow reached the lower part of Quebrada Chalala in darkness at 8:30 PM. It was preceded by a storm that began with the fall of hail followed by heavy rain for about 40 minutes from 8:00 to about 8:40 PM. At the Chalala village, it filled the $20 \mathrm{~m}$ wide channel to an estimated depth of $2 \mathrm{~m}$. The flow continued for about 10 minutes. It crossed Ruta 52 burying it to a depth of $50 \mathrm{~cm}$. It continued on to Río Purmamarca and crossed the channel but did not dam it. It was clearly a mudflow. It descended gradients as low as 2.5 degrees 
and had a plasticity index $>5 \%$ (Table 3). Comparison of Ikonos satellite images before and after determined that the flow originated in parts of the Lajayaco and Agualandre sub-basins.

\subsection{Prehistoric debris flows}

Bouldery debris flow levees occur at fan heads and deposits of debris flow diamicton locally occur up to $4 \mathrm{~m}$ above channel floors upstream from fan heads. They are the remains of the largest magnitude debris flows. Silent witnesses or radiocarbon dating assign these deposits to periods predating written or oral records (Table 5). The three principal tributaries of Quebrada Chalala join about $2 \mathrm{~km}$ above the Chalala village and mark the upper limit of the linear bedrockconfined alluvial fan of Quebrada Chalala (Fig. 1). Each tributary has evidence of prehistoric debris flows that were significantly larger than historical events. Quebrada Coquena emerges from a narrow bedrock valley upstream from station 50. The canyon splits into three tributaries about $1 \mathrm{~km}$ above station 50 (Fig. 1).

They have narrow bedrock-walled channels. Consequently, evidence of older and larger debris flows is confined to the area around station 50. Deposits in this area have muddy matrices similar to the 2007 debris flows. They indicate that previous events were also highly mobile mudflows e.g. Table 5, sample 36.

\section{Frequency and magnitude of debris flow hazard on fans of quebradas Coquena and Chalala}

Although only the debris flows of the 7 and 29 March 2007 have been investigated in detail, the combined historical and prehistoric evidence from the two basins can be used to place the two fans within established semi-quantitative hazard rating schemes. The two watersheds are geologically identical. Records from one can be used to corroborate, augment, and evaluate the record of the other. Debris flows large and mobile enough to traverse the entire lengths of the two fans and reach Río Purmamarca have occurred twice in 21 years. Smaller events have also occurred on both fans during that time. That record clearly places these fans in the very high probability $(<1 / 20)$ range of Hungr [6]. With respect to magnitude, the volume of the 2007 debris flow on the fan of Quebrada Coquena exceeded $10^{5} \mathrm{~m}^{3}$. The last large debris flow on the Quebrada Chalala fan in 1957 (Tables 2 and 5) was described as a volcán, a term reserved for an extremely large lahar-like mudflow in this region. Witnesses described it as being 4-5 $\mathrm{m}$ thick in the fan head (Fig. 1, B). Deposits from this event are apparently exposed at A (Fig. 1) and are at least $2 \mathrm{~m}$ thick at that mid fan location. Debris flows with volumes in the $10^{5}-10^{6} \mathrm{~m}^{3}$ range fall within Class 5 of the magnitude classification scheme of Jakob [9]. Such events are capable of destroying parts of villages such as Chalala, burying highways and blocking small rivers such as Río Purmamarca.

Although relative rating schemes employed above give a general evaluation for the debris flow hazard to Chalala village, design of debris flow defences such as protective dykes or dams and physical or computer modelling require more 
quantitative estimates of the largest debris flow likely to occur. Two methods were used to achieve this. They are described below.

\subsection{Method 1: extrapolation of peak discharge/total discharge relationships}

Power relationships between peak discharge $\left(\mathrm{Q}_{\mathrm{p}}\right)$ and total discharge $(\mathrm{V})$ of debris flows have been compiled for areas of the European and Japanese alps, North American cordillera and other mountainous regions [9,12]. These compilations have also characterized these power relationships based on debris flow texture and rheology e.g. bouldery and noncohesive debris flows versus very fluid mudflows. Reference to this literature permits application of power relationships expressed as $\mathrm{V}=\mathrm{c}_{\mathrm{p}}{ }^{\mathrm{n}}$ ( $\mathrm{c}$ is a dimensionless constant). A search of the literature found equation (3) of Bovis and Jakob [13] for very fluid debris flows from British Columbia, Canada to best approximate the peak to total discharge relationships seen along quebradas Coquena and Chalala.

$$
\mathrm{V}=338 \mathrm{Q}_{\mathrm{p}}^{0.99}
$$

The range of peak discharges calculated from data collected at station 50 (Table 4) yielded a range of predicted total discharges between $1.1 \times 10^{5}$ and $1.9 \times 10^{5} \mathrm{~m}^{3}$ with a mean of $1.4 \times 10^{5} \mathrm{~m}^{3}$. This compares well with the surveyed value of $1.5 \times 10^{5} \mathrm{~m}^{3}$. Table 6 computes the total discharges for basin-wide debris flows for Quebrada Coquena at Station 50 and for the Lajayaco fork of Quebrada Chalala using cross sectional channel areas from field measurement of the channel defined by the highest levees. An estimate of the discharge for the entire basin is made by scaling this discharge to the other sub-basins based on their relative areas.

Table 6: $\quad$ Predicted total volume (V) for the prehistoric debris flows from Quebrada Coquena and Lajayco fork (Quebrada Chalala), equation (3).

\begin{tabular}{|c|c|c|c|}
\hline Basin or sub-basin & $\begin{array}{l}\text { Channel cross } \\
\text { sectional area }\left(\mathrm{m}^{2}\right)\end{array}$ & $\begin{array}{l}\text { Estimated } Q_{p} \\
\left(\mathrm{~m}^{3} / \mathrm{s}\right) \text { assuming } \\
\mathrm{v}=7.9 \mathrm{~m} / \mathrm{s}\end{array}$ & $\begin{array}{l}\text { Predicted V }\left(\mathrm{m}^{3}\right) \\
\text { assuming V }=338 \mathrm{Q}_{\mathrm{p}}{ }^{0.99}\end{array}$ \\
\hline q. Coquena above sta. 50 & 98 & 776 & $2.5 \times 10^{5}$ \\
\hline q. Chalala (Lajayaco) & 63 & 498 & $1.6 \times 10^{5}$ \\
\hline \multicolumn{4}{|c|}{ Values for other Chalala tributaries scaled drainage area } \\
\hline q. Chalala (middle fork) & & & $1.3 \times 10^{5}$ \\
\hline Agualandre & & & $0.9 \times 10^{5}$ \\
\hline Total Chalala basin & & & $3.8 \times 10^{5}$ \\
\hline
\end{tabular}

\subsection{Method 2: modified JICA debris yield method}

This method was used in the investigation of debris flow hazard in the arid Río Rimac basin, Peru by the Japan International Cooperation Agency (JICA) [14] and Fidel et al. [15]. Total debris flow volume is predicted for a basin using sediment yield/unit basin area based upon yield ratios determined for the largest known debris flow in the local region. This is assumed to be a low probability event. The $5.6 \mathrm{~km}^{2}$ northern sub-basin of Quebrada Coquena (Fig. 1) was the source of the 7 March debris flow. We regarded this as a >1:20 year event. 
Although the north fork upper Coquena sub-basin is 36\% of the entire Quebrada Coquena basin, peak discharge from this event was in the order of $60 \%$ of that estimated for largest prehistoric debris flow based on field evidence at station 50 . The sediment yield ratio for north fork Quebrada Coquena ranged between $2.7 \times 10^{4}$ and $2.0 \times 10^{4} \mathrm{~m}^{3} / \mathrm{km}^{2}$ for this event (compare to $2 \times 10^{3} \mathrm{~m}^{3} / \mathrm{km}^{2}$ for the Lajayaco and Agualandre sub-basins, the sources of the 29 March, 2007 debris flow). Maximum and minimum estimates for total debris flow volumes based on these yield values are shown in Table 7 and are compared with the results of method 1 .

Table 7: Predicted maximum discharges using method 2 (JICA methodology).

\begin{tabular}{|l|l|l|l|l|}
\hline Basin or sub-basin & $\begin{array}{l}\text { Area } \\
\left(\mathrm{km}^{2}\right)\end{array}$ & $\begin{array}{l}\mathrm{V}(\text { yield ratio } \\
\left.2.7 \times 10^{4} \mathrm{~m}^{3} / \mathrm{km}^{2}\right)\end{array}$ & $\begin{array}{l}\mathrm{V}(\text { yield ratio } \\
\left.2.0 \times 10^{4} \mathrm{~m}^{3} / \mathrm{km}^{2}\right)\end{array}$ & $\begin{array}{l}\mathrm{V}\left(\mathrm{m}^{3}\right) \text { Table } \\
6(\text { Method } 1)\end{array}$ \\
\hline Coquena above station 50 & 12.4 & $3.3 \times 10^{5} \mathrm{~m}^{3}$ & $2.5 \times 10^{5} \mathrm{~m}^{3}$ & $2.5 \times 10^{5}$ \\
\hline $\begin{array}{l}\text { Chalala (all sub basins } \\
\text { above fan head) }\end{array}$ & 16.9 & $4.6 \times 10^{5} \mathrm{~m}^{3}$ & $3.4 \times 10^{5} \mathrm{~m}^{3}$ & $3.8 \times 10^{5}$ \\
\hline
\end{tabular}

\section{Discussion}

Methods 1 and 2 produced similar results for maximum debris flow volumes expected for the fans of quebradas Coquena and Chalala based upon different methods. As reassuring as this mutual corroboration appears, it must be noted that the data sets that were used by both methods were partly related. Consequently, it must be asked if there is any independent evidence to suggest that any of these estimated maximum debris flow volumes are realistic. We assert that geomorphic and stratigraphic evidence unrelated to these data sets can be used to evaluate whether or not they are realistic. With respect to method 2 (JICA method), maximum estimated debris flow volumes are based on the assumption that during the largest debris flow event, sediment is mobilized throughout the entire Chalala and Coquena basins at the yield rates determined for the source sub-basin (north fork) of the 7 March debris flow. For the Coquena basin, the highest and widest debris flow levees at station 50 define a channel with a cross sectional area of approximately 1.4 times that occupied by the 7 March debris flow. Assuming equation (3) and using a peak velocity of 8 $\mathrm{m} / \mathrm{s}$, a debris flow of $3.3 \times 10^{5} \mathrm{~m}^{3}$ would require a channel cross sectional area of approximately 1.3 times that of the 7 March debris flow. Thus, we conclude that the maximum specific yield value of $2.7 \times 10^{4} \mathrm{~m}^{3} / \mathrm{km}^{2}$ is reasonable value to apply to the entire basin for the largest debris flow to have occurred in the Coquena basin during the past several hundreds of years.

With respect to the Chalala basin, a maximum debris flow volume of $4.6 \times 10^{5}$ $\mathrm{m}^{3}$ is computed if the same specific yield value is applied (it is essentially geologically and physiographically identical to Coquena basin). A flow of this size would cover the fan of Quebrada Chalala to an average depth of approximately $1.8 \mathrm{~m}$. Our collection of oral accounts of debris flow events evidence indicates that the 1957 debris flow, which predates Chalala village, was 
apparently of this magnitude. Deposits several $m$ thick in the area of the fan head were reported by witnesses of this event. Stratigraphic evidence corroborates such an event on Chalala fan within this time frame. An exposure at Point A (Fig.1) shows a succession of stratified debris flow diamictons. The uppermost flow is $2 \mathrm{~m}$ thick. The same flow was thick enough to transport a $1 \mathrm{~m}^{3}$ quartzite block to the area of Chalala village. Judging by the lack of vegetation on this flow, it is only decades old and may date from either 1986 or the 1957 volcán (Table 5).

Based on this additional geomorphological evidence, we conclude that both methods 1 and 2 compute reasonable estimates for the volume of design debris flows. However, maximum values from method 2 appear to yield the most conservative estimates. This notwithstanding, the JICA method [14] applies an additional safety coefficient of 1.2 to allow for uncertainty. We suggest that it should be applied to method 2 estimates following JICA methodology.

\section{References}

[1] Carlotto, V., Fídel, L., Guzmán, A. Valenzuela, G.. and Huamaní, A., Colapso y fljo de detritos de Aobamba, Cusco, Perú, Proyecto Multinacional Andino: Geociencias para las Comunidades Andinas 2007. Movimientos en Masa en la Regíon Andina: Una guía para la evaluación de amenazas. Servicio Nacional de Geologia y Mineria, Publicación Geológica Multinacional, 4, pp. 303-307, 2007.

[2] González D., E.F., González, M. A., Ramallo Diego A., E., Flujo de detritos (alluvión) del 4 del abril del 2001 de Palma Sola, Jujuy, Argentina, Proyecto Multinacional Andino: Geociencias para las Comunidades Andinas 2007. Movimientos en Masa en la Regíon Andina: Una guía para la evaluación de amenazas. Servicio Nacional de Geologia y Mineria, Publicación Geológica Multinacional, 4, pp. 285-291. 2007.

[3] Salcedo, D.A. (2007) Flujo de detritos del Río Limón, al norte de Marcay, Estado Aragua, Venezuela. Proyecto Multinacional Andino: Geociencias para las Comunidades Andinas 2007. Movimientos en Masa en la Regíon Andina: Una guía para la evaluación de amenazas. Servicio Nacional de Geologia y Mineria, Publicación Geológica Multinacional, No. 4, pp. 269272.

[4] Estación Experimental INTA - SALTA. Instituto Nacional de Tecnología Agropecuaria. Boletín Desideratum Jueves 31 de Julio de 2003 - Año I - N ${ }^{o}$ 10. ISSN 1667-6580: http://www.inta.gov.ar/salta/info/boletines/ desideratum/boletin desideratum $10 . \mathrm{htm}$

[5] SEGEMAR Estudio geológico integrado de la quebrada de Humahuaca: Geología regional y geomorfología. Instituto De Geología Y Recursos Minerales. Buenos Aires, Argentina (CD-ROM), 1998.

[6] Hungr, O. Some methods of landslide hazard intensity mapping. Proceedings of a landslide risk workshop, ed. R. Fell \& D.M. Cruden, A.A. Balkema., Rotterdam, pp. 215-226, 1997. 
[7] Chow, V.T., Open channel hydraulics, McGraw Hill, New York, 680 p., 1959.

[8] Hungr, O, Evans, S.G., Bovis, M., \& Hutchison, J.N. Review of the classification of landslides of the flow type. Environmental and engineering geoscience, 4, pp. 231-228, 2001.

[9] Jakob, M., Debris-flow hazard and analysis, Debris flow hazards and related phenomena, ed. M. Jakob and O. Hungr,. Springer-Praxis books in geophysical sciences, Chichester, pp. 411-443, 2005.

[10] Jakob, M., Personal communication, October, 2007, Principal, BGC Engineering, Vancouver, Canada.

[11] Pierson, T.C., Hyperconcentrated flow - transitional process between water flow and debris flow, Debris flow hazards and related phenomena, ed. M. Jakob and O. Hungr, Springer-Praxis books in geophysical sciences, Chichester, pp. 159-202, 2005.

[12] Rickenmann, D., Empirical relationships for debris flows, Natural hazards, 19, pp. 47-77, 1999.

[13] Bovis, M.J. and Jakob, M., The role of debris supply conditions in predicting debris flow activity. Earth Surface Processes and Landforms, 24, pp. 1039-1054, 1999.

[14] Japan International Cooperation Agency (JICA). Final report for the master plan study on the disaster prevention project in the Rimac River basin. Japan International Cooperation agency, Tokyo, 6 vol., 1988.

[15] Fidel S., L., Zegarra L., J., Vilchez M., M., Franco-Castillo N., L., \& Jackson, L.E., Jr., Evolution of landslide activity, and the origin of debris flows in the El Niño affected Payhua Creek basin, Matucana area, Huarochiri, Peru, Proceedings, Engineering geology for tomorrow's cities, the 10th IAEG International Congress, Nottingham, United Kingdom, paper 32, 12 p., 2006. 